\title{
IMPROVING STUDENTS' PROBLEM SOLVING SKILL IN MATHEMATICS THROUGH WRITING
}

\author{
Linda Vitoria and Monawati \\ Syiah Kuala University, Indonesia \\ E-mail: lindav@unsyiah.ac.id
}

Received: Oct 28, 2015

Accepted: Jan 14, 2016

Published: May 28, 2016

Article Url: https://journal.scadindependent.org/index.php/jipeuradeun/article/view/100

\begin{abstract}
This article describes the implementation of writing in Mathematics as an effort to improve students' problem solving skill. The research method was classroom action research which was conducted in three cycles. Research participants were 24 first-year students at PGSD FKIP Syiah Kuala University. Data was collected using a written test consisted of mathematical word problems presented to the students at the end of each cycle, and interview. Students' problem solving skill was analyzed based on the four steps of problem solving proposed by Polya: 1 . the ability to understand the problem, 2 . the ability to plan a strategy to solve the problem, 3. the ability to execute the plan, and 4 . the ability to re-check. Result shows that writing in Mathematics improve students' problem solving skill. In cycle 1, the average score of students' problem solving skill was 51.7. In cycle 2, the average score was 75.6, and finally in cycle 3, the average score was 83.4. During interview, the students confessed that writing helped them organize their thinking so that they can solve a problem satisfactorily.
\end{abstract}

Keywords: Problem Solving, Writing in Mathematics 


\section{A. Introduction}

Students' problem solving skill is heavily influenced by the teaching and learning process in the classroom (Shulman \& Armitage, 2005). A meaningful mathematics learning does not only focus on procedural knowledge (knowing what), but also on conceptual knowledge (knowing how and knowing why). Conceptual knowledge can be shown by problem solving skill. Problem solving is an integrated part of learning mathematics because it promotes critical thinking skill which involves understanding, analyzing, and communicating of ideas. These activities are closely related to writing.

Previous studies have shown the positive impacts of writing in mathematics. Timothy and Quickenton (2005) reported that literacy improved pre-service teachers' understanding of mathematics. The implementation of literacy in learning mathematics helped students construct their understanding and at the same time improve their communication skill (Hunter, 2012; Johanning, 2008).

Writing in mathematics can be implemented in problem solving. Problem solving is an ability to solve a problem naturally (Komariah, 2011). Problem solving is an integrated part of learning mathematics because it promotes critical thinking (Tienken \& Maher, 2008). Writing can help students organize their thinking and solve a problem step by step. Polya's model of problem solving is probably the most familiar model among mathematics teachers. Polya's model consisted of four steps: 1 . Understand the problem, 2. Plan a strategy to solve the problem, 3. Carry out the plan, and 4. Re-check or examine the solution (Heidema, 2009). In this research, Polya's model was implemented to guide students' writing in solving a mathematical problem.

At the Department of Elementary Teacher Training Syiah Kuala University (PGSD FKIP Unsyiah), most of the students were not used to communicate ideas and opinions in written form. This condition influenced their problem solving ability. Generally, the students were able to solve problems in number format but they could not solve the same problem presented in word problems. Therefore this research was conducted to improve students' problem solving skill through writing in Mathematics. 
The research question addressed in this article is: how is the improvement of students' problem solving skill when writing is embedded in their mathematics learning?

\section{B. Method}

The method applied in this research was classroom action research which was conducted in three cycles. Each cycle consisted of four stages: plan, act, observe, and reflect as proposed by Kemmis and McTaggart (in Kunandar, 2010). The research took place at PGSD FKIP Unsyiah during Basic Mathematics Course in 2015. Twenty four students participated in the study.

The data in this study was students' problem solving ability. Data collection was conducted by test and interview. The test instrument was a written test containing mathematical problems related to number systems, integers, and rational numbers. Students' problem solving ability was descriptively analyzed based on Polya's problem solving model (Heidema, 2009): (1) The ability to identify the problem; (2) The ability to plan a strategy to solve the problem; (3) The ability to carry out the plan; and (4) The ability to re-check the solution.

The level of the students' problem solving skill was categorized according to the following classification (Arikunto, 2006):

Table 1. The Category of Students' Problem Solving Skill

\begin{tabular}{|c|c|}
\hline Score & Category \\
\hline $80<x \leq 100$ & Very Good \\
\hline $60<x \leq 80$ & Good \\
\hline $40<x \leq 60$ & Average \\
\hline $20<x \leq 40$ & Poor \\
\hline $0<x \leq 20$ & Very Poor \\
\hline
\end{tabular}

Students' problem solving skill is considered 'Good' if their average score for the four aspects of problem solving ability is in Good or Very Good category. 


\section{Discussion}

The following table shows the average score of students' problem solving ability.

Table 2: Students' Problem Solving Score

\begin{tabular}{|c|c|c|c|c|c|}
\hline \multirow[b]{2}{*}{ Cycle } & \multicolumn{4}{|c|}{ Problem Solving Skill } & \multirow[b]{2}{*}{$\begin{array}{c}\text { Average } \\
\text { Score }\end{array}$} \\
\hline & $\begin{array}{l}\text { The ability } \\
\text { to identify } \\
\text { the problem }\end{array}$ & $\begin{array}{l}\text { The ability to } \\
\text { plan a strategy } \\
\text { to solve the } \\
\text { problem }\end{array}$ & $\begin{array}{c}\text { The ability } \\
\text { to carry } \\
\text { out the } \\
\text { plan }\end{array}$ & $\begin{array}{c}\text { The ability } \\
\text { to re-check } \\
\text { the } \\
\text { solution }\end{array}$ & \\
\hline 1 & 45.4 & 41.2 & 59.6 & 60.4 & 51.7 \\
\hline 2 & 79.8 & 83 & 71 & 71.7 & 75.6 \\
\hline 3 & 85 & 85 & 81.7 & 83 & 83.4 \\
\hline
\end{tabular}

As shown in the table, the average score of students' problem solving skill in cycle 1 is Average, in cycle 2 Good, and in cycle 3 Very Good.

Data obtained through interview were as follow:

a. In cycle 1, the students faced difficulties in identifying the problem. Generally the students considered identifying a problem was the same as explaining the steps to be done to arrive at the final answer.

b. In cycles 2 and 3, there was improvement in the students' ability to identify problems. Most of the students were able to understand what was asked and wrote it correctly.

c. At first, the students were not used to write according to the steps of Polya's problem solving model. Most of the students immediately performed calculation without first identifying the problem and devising a plan to solve the problem. The students stated that they were not confident in their writing. They said that they could not put their ideas into orderly sentences.

d. The students who understood the problem were able to perform calculation, but they still found it difficult to write the solution in a good order.

e. During cycles 2 and 3 , the students stated that they improved their writing by avoiding excessive sentences. 
f. The students confessed that they were not used to write and problem solving, but they agreed that writing helped them think and work logically in solving a problem.

Result showed that writing has helped improve students' problem solving skill. The biggest improvement was in students' ability to identify problems and plan a strategy to solve the problem. In cycle 1, when asked to identify the problem, most of the students did not write down the problem correctly but instead they wrote the steps that they would do in solving the problem.

Figures $1(\mathrm{a})$ and $1(\mathrm{~b})$ below are examples of students' writing to identify the problem in the following word problem:

"Anto and Budi are playing detectives. They send messages in binary numbers. Anto texted: Jam dua (two c'clock). His first part of the message is: 101011101 . Write his complete message. When Budi received the message, he replied with 11111011 101. What does it mean?"

I. Problem Identification

1. Writing words into decimal numbers

2. Changing decimal numbers into binary numbers

3. Changing binary numbers into decimal numbers

4. Changing binary numbers into decimal numbers

Figure 1(a) A Student's Problem Identification

II. Problem Identification

1. Changing alphabets into decimal numbers

2. Changing decimal numbers into binary numbers

3. Translating Anto's message

4. Translating Budi's message

Figure 1(b) A Student's Problem Identification

As many as $62.5 \%$ students wrote their problem identification as shown in Figure 1(a), and 16.7\% wrote as in Figure 1(b). Another 12.5\% even wrote the whole solution when they were asked to identify the problem. Only $8.3 \%$ or 2 students were able to write problem identification satisfactorily. 
When interviewed, most of the students exhibited their understanding of the problem which was to translate Anto's and Budi's messages. But they did not fully understand the meaning of "identify the problem" so they were not sure what to write in this part of the problem solving. It showed that the students' ability to identify the problem was still poor. Therefore, for the next cycle, more familiar terms were utilized to help the students understand problem identification. The terms were 'diketahui' (what information is obtained from the problem) and 'ditanya' (what is asked by the problem).

In cycle 2, students' ability to identify the problem improved. The students were able to write down what was asked by the problem even though some students' sentences were less satisfactory because they re-wrote down the whole problem. Interview exposed that these students were concerned that they would not get the sentences right so they decided to rewrite the whole problem. In cycle 3, the students' ability to identify the problem was very good. The students showed satisfactory ability to identify a problem.

The aspect of planning a strategy to solve the problem was also improved greatly. In cycle 1, as many as $91.7 \%$ students were not able to write down their strategy satisfactorily. These students wrote down their calculation straight away without planning a strategy. During interview, these students confessed that they were not used to express their ideas in written form. They stated that they could imagine in their mind the procedure to solve the problem, but they did not know how to present it in words. They said they were not confident with their writing because they thought people would not understand their sentences. To overcome this problem, the students were encouraged to transform their ideas into words exactly the way they think them.

In cycle 2, the students showed improvement. As advised, they wrote down the words they had in mind. This improvement continued on through cycle 3. Interview showed that these students were able to get rid of their worry and be confident that if they could understand the strategy in their head, then they should write it exactly as how they thought it. The words did not have to be excessive; in fact simpler words were easier to understand.

The aspect of carrying out the calculation also improved. In cycle 1 , as many as $33.3 \%$ of the students did not write their calculation satisfactorily due to counting errors. The cause was lack of understanding 
of number properties. These students were asked to practice basic calculation to improve their calculation skill.

In cycle 2, 29\% of the students were still facing difficulties in calculation due to counting errors. During interview, it was apparent that these students were not able to conduct operations involving negative integers. These students were given calculation tasks to improve their calculation skill. In cycle 3, all of the students showed improvement in terms of their calculation ability. Among the $29 \%$ students whose calculation ability was Poor in cycle 2, five students improved to Good category and two students improved from Poor to Average.

The last step of Polya's problem solving model is to re-check the solution. The students were not used to do this. Interview in cycle 1 showed that when the students had finished their calculation, they would leave it at that. They would not take time to re-check if they got the answer right, or even if they had thoroughly finished the problem. When the students were asked to re-read the question and check if they had arrived at the final answer, they realized that they had not finished solving the problem.

In cycles 2 and 3, students' ability to re-check improved. During interview, they stated that the step to identify the problem and to re-check helped them to be more careful and thorough in their working. When re-checking their answer, they made sure that they had answered the problem satisfactorily.

\section{E. Conclusion}

Based on data, it can be concluded that writing in Mathematics helped improve students' problem solving skill. In cycle 1, the students did not show good ability in identifying a problem, planning a strategy to solve the problem, carrying out the plan, nor re-checking their answer. When presented with mathematical problems, the students were used to do calculation straight away without writing down problem identification and strategy. This led to miscalculation and incomplete answers. Writing the steps of problem solving helped the students to organize their thinking and their work neatly so that they could solve a problem well.

The difficulty that the students faced in problem solving was lack of understanding of basic number properties which is a prerequisite to solve any problems in mathematics. The students need to improve their mastery of 
basic calculation skill in order to be able to solve word problems and to learn more advanced topics in Mathematics.

\section{Bibliography}

Arikunto, S. (2006). Prosedur penelitian: Suatu pendekatan praktik [Research procedure: a practical approach]. Jakarta: PT Rieneka Cipta.

Heidema, C. (2009). Reading and writing to learn in Mathematics: Strategies to improve problem solving. Adolescent Literacy In Perspective, February 2009, 2-9.

Hunter, R. (2012). Coming to 'know' Mathematics through being scaffolded to 'talk and do' Mathematics. International Journal for Mathematics Teaching and Learning. Retrieved from http://www.cimt.plymouth.ac.uk/journal/hunter2.pdf

Johanning, D. I. (2008). Learning to use fractions: Examining middle school students emerging fraction literacy. Journal for Research in Mathematics Education, 39(3), 281-310.

Komariah, K. (2011). Penerapan metode pembelajaran problem solving model Polya untuk meningkatkan kemampuan memecahkan masalah bagi siswa kelas IX di SMPN 3 Cimahi [The implementation of Polya's problem solving model to improve students' problem solving ability for students grade IX at SMPN 3 Cimahi]. Yogyakarta: Prosiding Seminar Nasional Penelitian, Pendidikan dan Penerapan MIPA.

Kunandar. (2010). Langkah mudah penelitian tindakan kelas sebagai pengembangan profesi guru [Easy steps of classroom action research as teachers' professional development]. Jakarta: PT Raja Grafindo Persada.

Rajab, Tarmizi. (2015). An Applied Model of Teaching Materials to Improve Students' Speaking Skill. Jurnal Ilmiah Peuradeun, 3 (1), 103118.

Shulman, V., \& Armitage, D. (2005). Project discovery: An urban middle school reform effort. Education and Urban Society, 37(4), 371-397.

Tienken, C. H., \& Maher, J. A. (2008). The influence of computer-assisted instruction on eighth grade mathematics achievement. RMLE Online: Research in Middle Level Education, 32(3), 1-13.

Timothy, M. \& Quickenton, A. (2005). Effects of preservice teachers' math literacy in a tutorial field experience. International Journal for Mathematics Teaching and Learning. Retrieved from www.cimt.plymouth.ac.uk/journal/timothy.pdf.

Usman, Muhammad. (2015). Teaching Model of Learning English Writing at University. Jurnal Ilmiah Peuradeun, 3 (3), 441-450. 